\title{
Stakeholders' Perception of Residential Rental Value Determinants in Ghana
}

Emmanuel Kofi Gavu ${ }^{1,2}$, Dietwald Gruehn ${ }^{1}$, Karl-Werner Schulte ${ }^{3}$, and Lewis Abedi Asante ${ }^{4,5}$

${ }^{1}$ School of Spatial Planning, TU Dortmund University, Germany.

${ }^{2}$ Department of Land Economy, Kwame Nkrumah University of Science and Technology, Kumasi, Ghana.

${ }^{3}$ International Real Estate Business School, University Regensburg, Regensburg, Germany.

${ }^{4}$ Department of Geography, Humboldt University of Berlin, Germany.

${ }^{5}$ Department of Estate Management, Kumasi Technical University, Kumasi, Ghana.

To cite this article: Gavu, E.K., Gruehn, D., Schulte, K-W. \& Asante, L.A. (2019). Stakeholders' perception of residential rental value determinants in Ghana. Journal of African Real Estate Research, 4(1), pp.42-70. DOI: 10.15641/jarer.v4i1.704.

\begin{abstract}
The determinants of Residential Rental Values (RRVs) have been analysed differently by housing researchers across the globe. This paper scrutinises the perception of stakeholders in Accra's housing market in order to identify and conceptualise commonalities and differences in variables that determine RRVs. It adopts relative importance index to rank 38 different variables that determine RRVs. Using the stratified sampling technique, the population of experts and stakeholders with knowledge in the rental market space were identified and categorised into six distinct strata. The sample frame was drawn from landlords; tenants; real estate agents; academic staff from real estate departments in universities; valuation and estate surveyors; and a group labelled as 'others'. Purposive sampling was then used to identify respondents within each stratum. The findings suggest that electricity and piped water connection, type of house, property condition and number of bedrooms are the most significant determinants of RRVs in Accra. Contrariwise, the least significant variables include storeroom availability, proximity to recreational facilities, proximity to place of worship, landscape quality and number of storeys. This study contextualises RRVs by identifying variables that reflect characteristics of the rental housing market in Accra. This paper serves as a guide in understanding rental market dynamics in a typical African city where access to data remains a challenge.
\end{abstract}

Keywords: Perceived Value; Rent; Stakeholders; Real Estate; Relative Importance Index 


\section{Introduction}

In many African countries the majority of the people reside in rental housing (Mahama \& Adarkwa, 2006; UN-Habitat, 2011b; Asante et al., 2018). In Ghana about $40 \%$ of the population are tenants (Ghana Statistical Service, 2014). Rental housing is not only an important housing option for the urban poor but also middle and high-income populations in Africa. According to the UN-Habitat (2011b: p.3), "rental housing is an integral part of a wellfunctioning housing market". Further, it is noted that rental housing markets are influenced by a broad spectrum of stakeholders; and respond to local economic, social, regulatory and political realities, whilst operating differently from one city to another. In Ghana and most parts of Africa, more than $90 \%$ of tenants rent accommodation from private landlords (ObengOdoom, 2011a; 2011b).

Landlords have been perceived as exploitative toward tenants given 'unrealistic' (high and exorbitant) rents and ineffective regulatory mechanisms (Gough \& Yankson, 2000; 2011; Yankson, 2012; Amenyah \& Fletcher, 2013; Owusu-Ansah \& Abdulai, 2014; Asante et al., 2018; OwusuAnsah et al., 2018). Anecdotal evidence suggests that without landlords doing any 'proper' market research or consulting real estate professionals, they unilaterally fix rental values. Valuers, on the other hand, have also been criticised for not providing accurate valuations due to the disparities between market observed rental values (charged to tenants) and values reported in valuation reports (perceived); which are either overestimated or underestimated (Baffour Awuah et al., 2016). These disparities in Residential Rental Values (RRVs) arise due to the predominantly informal nature of the rental housing market in Ghana. In spite of the informal nature of the market, if these RRVs are properly analysed based on sound market considerations, it may guide market players in assigning realistic values to rental units. Roulac $(2001 ; 2007)$ suggests that researchers have primarily used physical metrics of age and size, among others, as the explanatory variables that determine a residential property's value relative to other property data samples. This emphasis has been on statistical correlation (for example ANOVA and multiple regression analysis) rather than the fundamental issue of causation. Roulac's concern emphasises the need to also focus on the causes of these correlations. Thus, these studies are critical in understanding how the rental pricing regime works and also serve as a standardised measure in rental housing markets research and analysis. These studies also enable the construction and analyses of rental values from the perspective of players on both the demand and supplier sides of the rental housing market.

RRVs that are observed in the market have individual utility bearing attributes (explanatory variables) that could be modelled to ascertain their effects on rental value. Due to data asymmetries and the lack of a consistent datasets, especially in Africa's housing market, most studies draw on a few 'available' sources (mostly from aggregated census data, data from land sector agencies and valuation reports) to empirically model RRV determinants (OwusuAnsah, 2012a). This makes it practically impossible to compare analyses on rental value determinants on a standardised basis. 
In Nigeria (Arimah, 1992; Adegoke, 2014), Kenya (Gulyani \& Talukdar, 2008), Togo (Choumert, Kere, \& Laré, 2015) and Uganda (Knight, Herrin, \& Balihuta, 2004), the extant literature has focused on the effects of specific location and neighbourhood attributes on rental value. In Ghana, for example, studies such as Anim-Odame et al. (2010a), Anim-Odame et al. (2010b), Owusu-Ansah (2012a), Owusu-Ansah and Abdulai (2014), Owusu-Ansah et al. (2017), have relied on data from land sector agencies and valuation reports to examine the dynamics of the property markets in Kumasi, Accra and Tema. These studies, however, were limited to residential property values and price dynamics. On the rental market, Owusu-Ansah et al. (2018) have examined the nature of rental contracts. These studies did not examine market stakeholders' understanding of value dynamics in order to understand how these perceptions may translate to observed value on the property market. Although Abidoye and Chan (2016) examine the determinants of residential value by analysing perceptions of professional valuers in Nigeria, the study excluded other key stakeholders in the housing market like landlords, tenants, real estate agents and academics (university staff) teaching in real estate departments.

Productivity theory serves as a guide in explaining the perception of value. This theory is based on the belief that the productivity of a real estate unit is dependent on how different attributes are combined and how different market stakeholders react to these attributes (Ratcliff, 1961; Lancaster, 1966; Lundgren, 2013). Different stakeholder groups in the housing market seek different attributes from the use of a particular real estate unit. This results in differences in rental value perceived by these stakeholders. Thus, all attributes that are perceived to influence value are critically analysed by stakeholders depending on the objective they seek from the use of such real estate. This begs the question, what explains the differences in residential rental spaces within the built environment? An attempt is made in this study to analyse trends in commonalities and differences in value perceptions among the various stakeholder groups. From the literature, it can be concluded that although some work has been done on housing markets within the sub-region, no attention has been given to how key stakeholders perceive and rank residential rental value determinants. As noted by the UN-Habitat (2011b: p.4), "it is important that policymakers understand the intricacies of their cities' rental housing (both formal and informal) and know how to formulate effective, flexible policies to promote and regulate it." It must be appreciated that these stakeholders' interaction with the market determine, to a large extent, values of properties which researchers can use to unravel determinants of value. This study is developed as a response to gaining a better understanding on rental value determinants.

Value perception can be studied through various lenses. Furthermore, the way in which market stakeholders perceive rental value determinants provides feedback for empirical analysis. Interestingly, there is very little research on this subject matter within the Ghanaian literature. We fill this knowledge gap by extending the spatial scope of the discussion. By using a survey, the research examines the perception of key stakeholders in the rental market. These stakeholder perceptions are ranked using the Relative Importance 
Index (RII). This approach enables researchers to identify data that are relevant to empirically model market interactions.

The entire paper is structured into six sections. The introduction provides an overview and contextualises the research. Section 2 is a review of the literature on explanatory variables that determine residential rental value, while Section 3 gives a brief overview of the structure of the residential rental housing market in Ghana. Section 4 discusses the methodology adopted for the research. Sections 5 present data analysis, results and discussion. Lastly, Section 6 presents the conclusion and implications of the research on the Ghanaian rental market.

\section{Theoretical Framework: Explanatory Variables that Determine Rental Value - Evidence from Extant Literature}

A variety of theoretical and econometric studies have explored the determinants of house prices (Tse, 2002). One of the theories that help in this regard is Location Theory; attributable to Heinrich von Thünen's theory of location of agricultural land uses in his book 'Der Isolierte Staat' and Alfred Weber's theory of location of manufacturing industries. von Thünen's depiction of concentric circles of agricultural activities or uses around the consuming centre is a useful and good starting point for research in this field (Predöhl, 1928). In his model, those paying higher prices at the consuming centre are compensated by lower costs of commuting to the CBD. The relationship between house prices and location are as a result of unobservable variations in location across properties coupled with a heterogeneous market.

Originally, land rent theory focused on agriculture and the price and value of a product. The debate as to whether land rent theory as developed for agriculture is applicable to the urban situation has been debated by several scholars (Harvey 1973; Ball 1977; Ball 1985a; Ball 1985b; Lipietz 1985; as cited in Haila 2016). One assumption of urban economic models has been that rents decrease with distance from the city centre. However Haila (2016: p.59) posits that "empirical research has neither verified nor disproved this". When rents increase with distance it is explained that perhaps the neighbourhood and quality of the environment is superior compared to others.

Ozanne and Thibodeau (1983) posit that the quality of a location has a ripple effect on house prices within that particular neighbourhood. They depict that in a particular neighbourhood, the quality of a property can be mimicked or duplicated, resulting in every property having similar qualities over time. The same will hold true for low quality properties in a neighbourhood. Figure 1 shows that with the passage of time, a whole neighbourhood can have one common identity in terms of neighbourhood characteristics. On the left-hand side of Figure 1, quality housing is depicted but scattered within a particular neighbourhood, over time other properties mimic the trend and eventually show a similar identity.

One thing worth noting in this model is that better quality properties could reflect the quality of location, which will in turn have a ripple effect to induce 
more quality housing in that particular neighbourhood or geographical area. Higher income metropolitan areas will generally have more new houses of better quality and a large size. Where there are inter metropolitan variations, it will contribute to house price variations.

A house is composed of characteristics which together affect its rental value. These include physical (structural), locational, neighbourhood and environmental characteristics. There is disagreement as to how much each of these attributes influence rental values (Harrison \& Rubinfeld, 1978; Arimah, 1992; Sirmans, Macpherson, \& Zietz, 2005; De \& Vupru, 2017). Value could be defined as the importance of something, in this case, the value of a residential property or the anticipated benefits from the market perspective. There is no single universal agreement to the definition of value. Some researchers complicate the discussion on value by asking, is it value in exchange, the value in use or cost to a market participant?

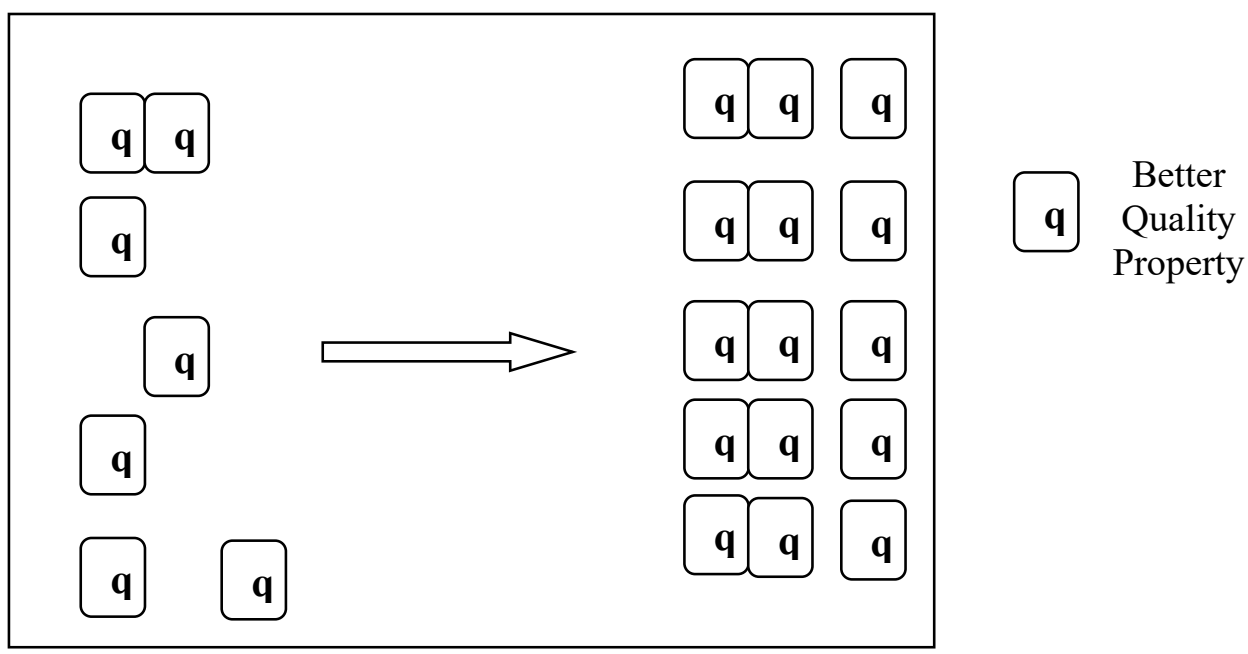

\section{Figure 1: Ripple Effect to Induce more Quality Housing Theory (adapted from Tse 2002; Ozanne \& Thibodeau 1983)}

Ideally in the rental market, the basis of value in an arm's length transaction should be market rent. Which is defined as "the estimated amount for which an interest in real property should be leased on the valuation date between a willing lessor and a willing lessee on appropriate lease terms in an arm's length transaction, after proper marketing and where the parties had each acted knowledgeably, prudently and without compulsion" (International Valuation Standards Council, 2017: p.21).

In this research however, the focus is on perceived value. Perceived value is value as observed by a particular market participant (or stakeholder) based on interactions within the housing market. Zeithaml (1988) describes four categories of perceived value, namely:

1. Value is low price,

2. value is whatever I want in a product,

3. value is the quality I get for the price I pay, and 
4. value is what I get for what I give.

Explanatory variables of the price build-up of real estate units show a particular trend in developed countries (Sirmans et al., 2005). Sirmans et al. identify a list of 20 housing characteristics appearing most often in hedonic pricing model studies. They assert that bathrooms, bedrooms, public rooms, garages, fireplaces, pools, and area of the real estate unit are key explanatory variables that consistently show a positive sign across various regions when a hedonic pricing model is adopted. A careful consideration of variables provided by Sirmans et al. suggests that structural variables appear to be dominant in the discourse. This is interesting and offers a one-sided picture as locational and neighbourhood variables are missing in this list. There is however vast empirical research that suggests that locational and neighbourhood variables that affects rental values may vary across social and economic groups (De \& Vupru, 2017). In a developing country context like Ghana, variables like a fireplace, air-conditioning and pool, which are absent in many homes, may not be relevant factors to determine rental values.

This research draws conclusions from market stakeholder perceptions on both the formal and informal rental housing markets in Ghana. The available literature shows that there is limited recorded research on how these variables have been modelled and variables that are significant in one market may be different in another.

The influence of location attributes on rental value may not be as simplistic as previously envisaged. For example, location may be influential in determining rental values in both developed and developing countries. The seminal works of Wilson $(1992 ; 2012)$ and Connolly (2014) address the issues of origins of residential segregation, problems of ghetto neighbourhoods, inner city poverty, out-migration in inner-city neighbourhoods and problems of rural-urban migration in America. These examples give credence to the fact that negative neighbourhood problems lead to worsening rental conditions. Which in effect influences rental values negatively. These problems are not only confined to developing countries but developed countries as well.

Table 1 shows the list of explanatory variables that have been utilised in both developed and developing country contexts for illustrative purposes. It can be noted that various researchers have utilised different variables to explain the determinants of rental value. In a developing country context, the number of bathrooms and location of property seem to be the predominant variables (Arimah, 1992; Asabere, 2004; Knight et al., 2004; Asabere, 2007; Gulyani \& Talukdar, 2008; Anim-Odame et al., 2010a, 2010b; Owusu-Ansah, 2012b; Adegoke, 2014; Choumert et al., 2015; Abidoye \& Chan, 2016). The location variable is not defined and lumped together as one variable. This actually masks the different aspects of location that could be modelled. However, there seems to be some convergence with variables used in the developed country context (Malpezzi, 2002; Sirmans et al., 2005) (i.e. the age of the property, floor area, number of storeys, number of bathrooms and bedrooms).

Other African case studies further expand on these variable relationships. In Kenya, a multivariate analysis of what drives rental values in Nairobi's 
informal rental housing market suggests that factors such as: the number of rooms, building quality, permanent walls, permanent floor, electricity and water availability, reasonable access to toilet, and the presence of public school in the neighbourhood are critical in rent determination (Gulyani \& Talukdar, 2008). The authors posit that the informal market mimics the formal market in that rental values are determined by the unit's size, location, construction quality and access to infrastructure.

The modelling of Uganda's real estate market shows different determinants of rental value. Using the Uganda National Housing Survey data, Knight et al. (2004) show that electricity and water availability, toilet facility, construction quality, number of rooms, location, distance from the CBD and type of land tenure are significant determinants of rent.

\section{Table 1: Key Explanatory Variables Used in Extant Literature (Especially in Developing Countries in Africa)}

\begin{tabular}{|c|c|c|c|c|c|c|c|c|c|c|c|c|c|c|c|c|}
\hline \multirow[b]{2}{*}{ Category } & \multirow[b]{2}{*}{ Dimension } & \multirow[b]{2}{*}{ 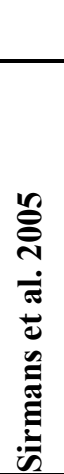 } & \multirow[b]{2}{*}{ 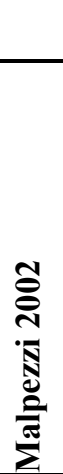 } & \multicolumn{13}{|c|}{ Developing Country Evidence } \\
\hline & & & & $\frac{\widetilde{\Omega}}{2}$ & 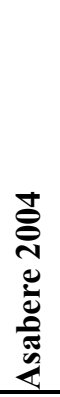 & 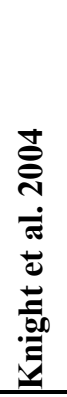 & 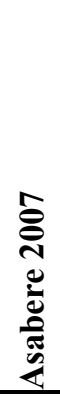 & 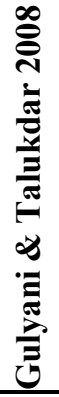 & 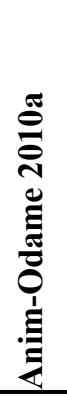 & 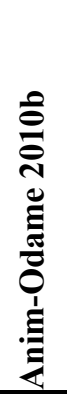 & 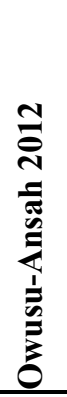 & 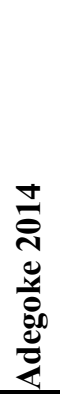 & 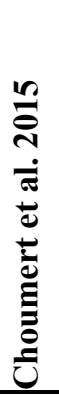 & 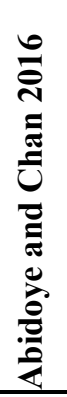 & 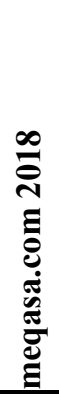 & 量 \\
\hline \multirow{23}{*}{ 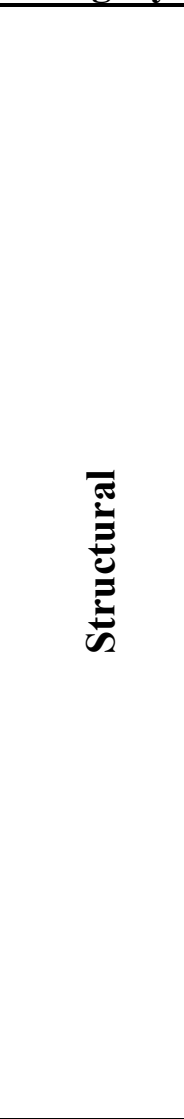 } & Real estate type & & & & & & & & $\mathrm{X}$ & $\mathrm{X}$ & & & & & $\mathrm{X}$ & 3 \\
\hline & Age of rental property & $\mathrm{X}$ & $\mathrm{X}$ & & & & $\mathrm{X}$ & & & & $\mathrm{X}$ & & & $\mathrm{X}$ & & 5 \\
\hline & Lot size & & & & $\mathrm{X}$ & & $\mathrm{X}$ & & & $\mathrm{X}$ & & & & & $\mathrm{X}$ & 4 \\
\hline & Total floor area in sqm. & $\mathrm{X}$ & $\mathrm{X}$ & $\mathrm{X}$ & & & & & $\mathrm{X}$ & $\mathrm{X}$ & & & & $\mathrm{X}$ & & 6 \\
\hline & Number of floors/ storeys & $\mathrm{X}$ & $\mathrm{X}$ & & & & $\mathrm{X}$ & & & $\mathrm{X}$ & & & & & & 4 \\
\hline & Public room & $\mathrm{X}$ & & & & & & & & & $\mathrm{X}$ & $\mathrm{X}$ & & & & 3 \\
\hline & Number of bedrooms & $\mathrm{X}$ & $\mathrm{X}$ & $\mathrm{X}$ & & $\mathrm{X}$ & & $\mathrm{X}$ & & $\mathrm{X}$ & $\mathrm{X}$ & & $\mathrm{X}$ & & & 8 \\
\hline & Number of WC/ toilet & & & & & $\mathrm{X}$ & & & & & & $\mathrm{X}$ & & & & 2 \\
\hline & Type of toilet facility & & & & & & & $\mathrm{X}$ & & & & & $\mathrm{X}$ & & & 2 \\
\hline & Number of bathrooms & $\mathrm{X}$ & $\mathrm{X}$ & & & & & & & & $\mathrm{X}$ & $\mathrm{X}$ & & & & 4 \\
\hline & Floor finish & & & & & & & $\mathrm{X}$ & & & & & $\mathrm{X}$ & & & 2 \\
\hline & Fence wall availability & & & & & & & & & & $\mathrm{X}$ & & & & & 1 \\
\hline & $\begin{array}{l}\text { Parking space (Garage or } \\
\text { outhouse) available? }\end{array}$ & $\mathrm{X}$ & $\mathrm{X}$ & & & & & & & $\mathrm{X}$ & $\mathrm{X}$ & & & & & 4 \\
\hline & Construction quality & & & & & $\mathrm{X}$ & & $\mathrm{X}$ & & & & & & & & 2 \\
\hline & Quality of landscaping & & & & & & & & $\mathrm{X}$ & $\mathrm{X}$ & & & & & & 2 \\
\hline & $\begin{array}{l}\text { Property condition/ } \\
\text { Physical deterioration }\end{array}$ & & & & & & & & & & & & & $\mathrm{X}$ & & 1 \\
\hline & Pool area (swimming pool) & $\mathrm{X}$ & & & & & & & & & $\mathrm{X}$ & & & & & 2 \\
\hline & Fireplace & $\mathrm{X}$ & & & & & & & & & & & & & & 1 \\
\hline & Burglar alarm & & & & & & & & & & & $\mathrm{X}$ & & & & 1 \\
\hline & Air-conditioning & $\mathrm{X}$ & & & & & & & & & & & & & & 1 \\
\hline & Security of Tenure & & & & $\mathrm{X}$ & & & & & $\mathrm{X}$ & $\mathrm{X}$ & & & & & 3 \\
\hline & $\begin{array}{l}\text { Tenure type (leasehold or } \\
\text { freehold) }\end{array}$ & & & & & $\mathrm{X}$ & $\mathrm{X}$ & & & $\mathrm{X}$ & & & & & & 3 \\
\hline & Shared facility & & & $\mathrm{X}$ & & & & & & & & & & & & 1 \\
\hline
\end{tabular}




\begin{tabular}{|c|c|c|c|c|c|c|c|c|c|c|c|c|}
\hline \multirow{6}{*}{ } & Location of property & & & $\mathrm{X}$ & & & $\mathrm{X}$ & $\mathrm{X}$ & $\mathrm{X}$ & $\mathrm{X}$ & $\mathrm{X}$ & 6 \\
\hline & $\begin{array}{l}\text { Near to market or shopping } \\
\text { centre }\end{array}$ & & & & $\mathrm{X}$ & & & & & & & 1 \\
\hline & Near to CBD & $\mathrm{X}$ & $\mathrm{X}$ & $\mathrm{X}$ & & & & & & & & 3 \\
\hline & $\begin{array}{l}\text { Near to educational } \\
\text { facilities }\end{array}$ & $\mathrm{X}$ & & & & $\mathrm{X}$ & & & & & & 2 \\
\hline & $\begin{array}{l}\text { Near to police station } \\
\text { (security) }\end{array}$ & & & & & & & & & $\mathrm{X}$ & & 1 \\
\hline & Access and time variable & & $\mathrm{X}$ & & & & & & & & & 1 \\
\hline \multirow{4}{*}{ 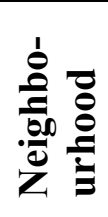 } & Neighbourhood class & & $\mathrm{X}$ & & & & & & & & $\mathrm{X}$ & 2 \\
\hline & $\begin{array}{l}\text { Neighbourhood } \\
\text { characteristics }\end{array}$ & & & & & & & & & $\mathrm{X}$ & $\mathrm{X}$ & 2 \\
\hline & Electricity connection & $\mathrm{X}$ & $\mathrm{X}$ & $\mathrm{X}$ & & $\mathrm{X}$ & & & & & & 4 \\
\hline & Water availability & & & $\mathrm{X}$ & & $\mathrm{X}$ & & & & & & 2 \\
\hline
\end{tabular}

Source: Authors' Construct, 2018.

In the Nigerian literature, Arimah (1992) asserts that floor area, number of bedrooms, electricity connection, proximity to educational facilities and $\mathrm{CBD}$, and whether the property is a shared facility or otherwise, are the significant determinants of rent in Ibadan. Adegoke (2014) posits that different critical factors influence RRVs of different building types in different residential densities. The findings show that the number of toilets, number of bathrooms, living rooms and presence of burglar alarm are key determinants of rent in Ibadan in Nigeria. Also, Abidoye and Chan's (2016) findings (based on perceptions of professional valuers in Nigeria) reveal that property location, neighbourhood characteristics, state of property repair, size of the property, neighbourhood security, age of property are most highly significant influence on residential property value.

In Ghana, Buckley and Mathema (2007) use household income and household size to model housing demand. Asabere (2004) considers lot size, distance to CBD, neighbourhood class, electricity and water availability, type of tenure, access and time variables to price leasehold and freehold interests using hedonic analysis. In another study, Asabere (2007) utilises the number of storeys, plot size, age and location to model the market in Tema.

Anim-Odame et al. (2010a; 2010b) and Owusu-Ansah and Abdulai (2014) use similar datasets from the Land Valuation Division of the Ghana Lands Commission to develop housing price indices for Accra. The explanatory variables are sale price/rent, number of bedrooms, number of storeys, plot size, floor area, tenure or tenancy term certainty, the presence of a garage or outhouse, quality of landscaping, real estate type (detached or semidetached), and security of tenure. Anim-Odame et al. use a hedonic model to analyse the influence of residential attributes on price and rent and also to test submarket performance. They conclude that the number of bedrooms and an unexpired term are not statistically significant, while all other variables have expected signs for the rental market. Using cross-sectional data, OwusuAnsah (2012a) establishes that the number of bedrooms, bathrooms, living rooms, the age of the property, the location of the property, availability of a garage, fence wall, swimming pool, and land registration influences real estate values in urban Ghana. The number of floors was found to have the least impact on price. 
All the aforementioned country-specific examples give credence to the assertion that it is not possible to compare value determinants on a standardised basis. This is due to the paucity of data in Africa's rental housing market. And also due to the fact that different variables are utilised to disaggregate value. There is, however, another construct that has been developed to analyse explanatory variables in housing market analysis. The Brand, Beauty and Utility (BBU) model, developed by Stephen Roulac, is discussed in the next paragraph.

The BBU concept examines the role that brand, beauty and utility play in defining property value with a place construct (Roulac, 2001). On a broader conceptual level, the value of a property is determined by its use. This concept seems to align with the Marxist theory of rent that suggests a dialectical relationship between use and exchange in value. Owusu-Ansah et al. (2018) mention that the Marxist theory of rent offers relevant theoretical insights in that it suggests a strong link between use and exchange in value. The BBU model builds on the location theory of economic activities by focusing on what real estate practitioners mean when they say location and neighbourhood factors determines the value of property. Roulac (2001: p.429) explains that "the price that a property commands in the market place effectively is a payment for the right to rent and control the sensory experiences of utility, brand and beauty." For rental property, a (prospective) tenant assesses the worth of the whole value package of brand, beauty and utility. Quantifying the 'correct' set of independent variables that determine rental value may be a daunting task. There are some perceived challenges in quantifying variable effects (Anim-Odame et al., 2010b; Helbich et al., 2013; Gilbert, 2016). These are outlined below:

1. It may be difficult to identify and measure those factors that are important variables in determining value. The question here is what is important to be measured and how do we identify them?

2. Some of the effects may not be readily noticeable or may be nonlinear. The question here would be how do we account for factors that we may not be aware of?

3. It may be difficult to separate or draw a fine line between individual property characteristics (that affect value), location and neighbourhood factors, and how these individual factors contribute to price in the real estate market. How do these interrelationships interact to determine rental value in the market?

The failure to adequately address these questions in the methodology may yield results that may understate or overstate the effects of explanatory variables on rental value. Rental values affect household expenditure and spending patterns through the Wealth Effect in the broader macro economy. When explanatory variables that cause changes in value from one location to another are uncovered it can help improve the underlying constituents of differential rents from key stakeholder perspectives. When the effects of location or locational attributes are separated from rental values, two effects are envisaged. Firstly, rental values can be analysed on a standardised basis. Secondly, the contribution of location and neighbourhood attributes can be analysed to estimate its impact on rental values. 
How rental systems operate has been widely theorised and shapes the ways in which rent phenomena are understood. It must be noted that the Georgist analysis of rent argue that landlords continue to wield power over both tenants and the state; whereas Marxists theories of rent suggests a didactical relationship between use and exchange in value (see Obeng-Odoom 2015 for a full discussion). In other words, Marxists advocate the nationalisation of land, whereas Georgists taxing land rent. However, Ghana's market follows a free market model (likened to the neoliberal ideology). As Owusu-Ansah et al. (2018) rightly opine, rental housing provision in Ghana has switched from state-led development to market-based development. It is argued that the Ghanaian market is unique in itself and that a more grounded, contextspecific understanding of the rental market would be the preferred theory that explains the conceptualisation of rent. A full discussion of how these theories are operationalised are outside the scope of this paper ${ }^{1}$. The foregone discussions lead to the next section which presents an overview of the peculiar situation of the rental housing market in Ghana. This is to allow readers to appreciate the local housing context within which the research is based.

\section{The Nature of the Residential Rental Housing Market in Ghana - An Overview}

The residential rental housing market in Ghana, just like other housing markets within the Sub-Saharan African (SSA) region is characterised by high demand over available supply; high rental values coupled with generally low incomes; and government policy focus on homeownership with less attention to the rental housing market. Ghana's market follows a free-market model with the active participation of the private sector as the main suppliers of new developments (Tipple \& Korboe, 1998; Arku, 2009a, 2009b). The current role of government is as a policy regulator that provides an enabling environment to developers for housing supply. Many attempts by the government of Ghana, policy-wise, promote home-ownership. However, not everyone can afford property; thus, rental housing is on the ascendency. UNESCAP and UN-Habitat (2008) underscore the need to holistically analyse the housing market and posit that "it is a common misperception that everyone wants to own a house. For many people, rental housing is a better option" (2008: p.1).

Ghana's national housing policy is aimed at "creating viable and sustainable communities through the provision of adequate, decent and affordable housing that is accessible and sustainable to satisfy the needs of Ghanaians" (Government of Ghana, 2015: p.14). To reduce the over 1.7 million housing deficit (Salifu Osumanu et al., 2018) the government's approach has been to provide an 'enabling environment' by extending key infrastructure for the private sector to lead the way in housing supply.

\footnotetext{
${ }^{1}$ Anne Haila presents an interesting exposition on the theories of land rent (see chapters 2 to 5 Haila, 2016)
} 
Anecdotal evidence suggests that the real estate market is segmented and highly heterogeneous in terms of property type. The Ghanaian rental market is generally of two typologies: a formal and informal market (Figure 2). The formal market is more structured and consists of gated communities and estate buildings. These areas have access to basic infrastructure, and developers conform to required planning and building standards. A greater number of the housing stock is exclusively for sale with rents priced in United States Dollars (Arku et al., 2012).

The informal market is part of the urban fabric because of the phenomenon of urban sprawl. The urban poor occupy such areas as they cannot afford rents in neighbourhoods where better housing exists. The informal market is utilised by the majority of the population for housing supply due to low incomes. This market is generally of poor quality and lacks access to basic infrastructure. Landlords in this market operate outside the legal regime and are believed to exploit tenants because of housing shortages. Arku et al. (2012) explain that most houses in the informal market are overcrowded, without planning permits, poorly sited and with no access for emergency services when disaster strikes. The informal market is dominated by what is known as traditional compound houses (see Figure 3) which is home to the majority of the population. A compound house is a single or multi-storey, semi-detached building, where occupants share and utilise a common compound.

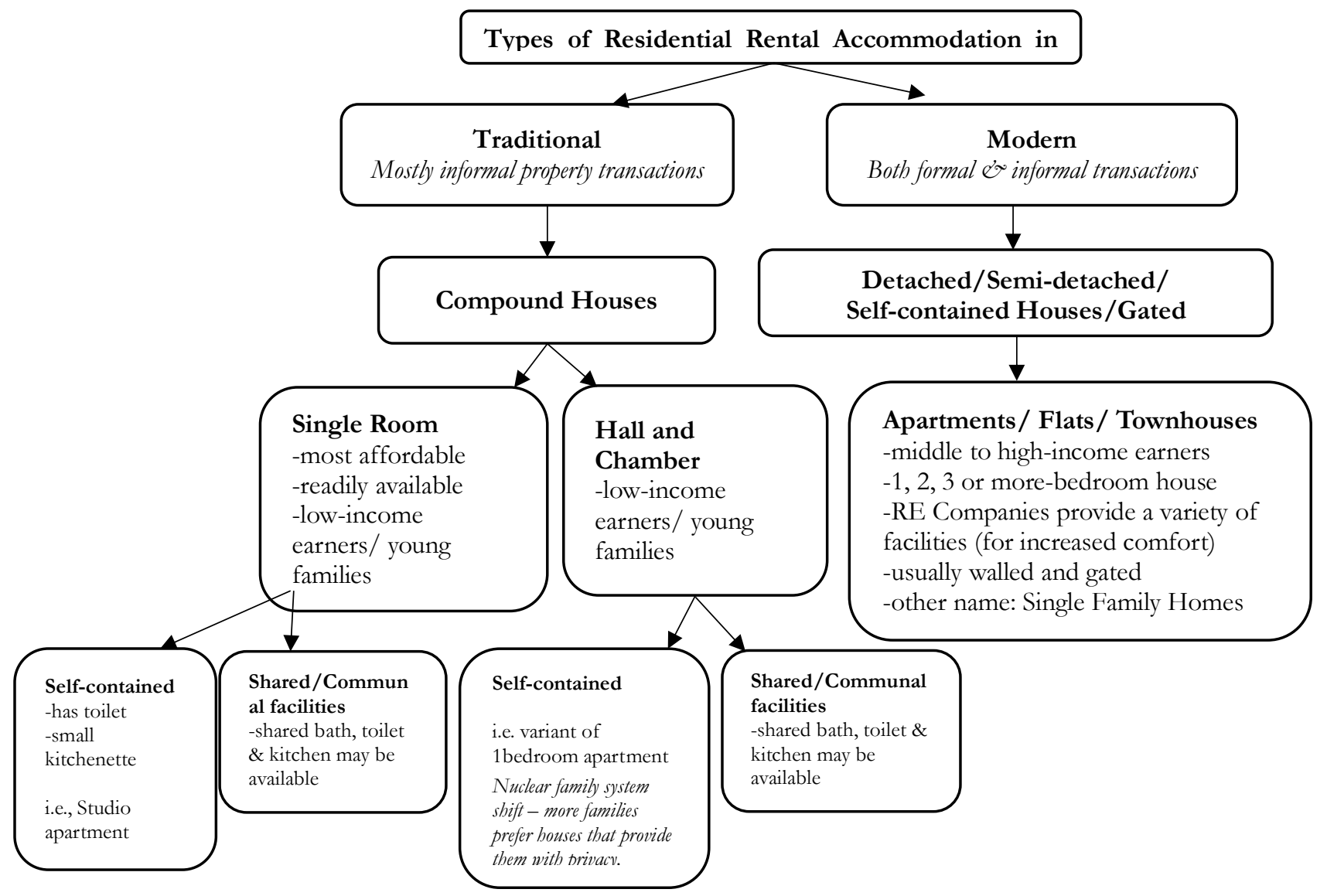

Figure 2: Residential Rental Accommodation Types in Ghana Source: Authors' Construct, 2018. 
Two main types of houses are available for low-income earners in compound houses; 'single rooms' and 'hall-and-chamber units'. The 'single rooms' consist of one room that serves as both a living area and bedroom for an occupant. 'Hall-and-chamber' units have two rooms, one used as a living room (which can be converted to a bedroom based on family size) and the other as a bedroom.
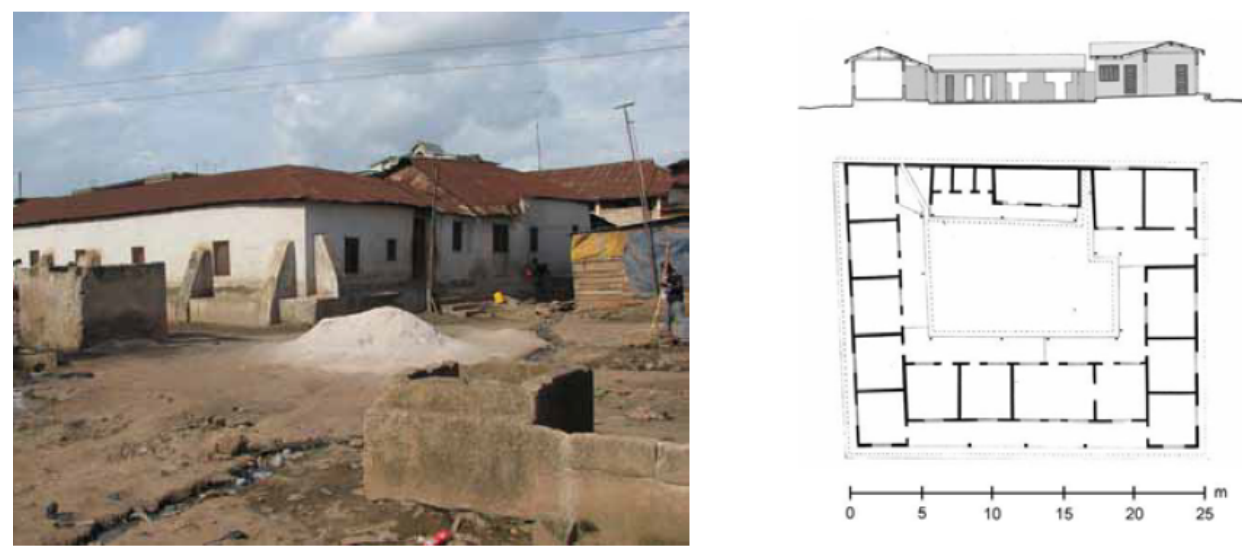

Figure 3: Traditional Compound House and Plan

Source: UN-Habitat, 2011 a (Photo Credit: G Tipple \& Royal Danish Academy of Fine Arts)

\section{Methodology}

\subsection{Survey Design}

Real estate, like other sectors of the economy, has different mechanisms for setting prices in the market. These may differ from the theoretical framework of demand and supply. As a heterogeneous good, how different factors interact to fix prices may be perceived differently by stakeholders in the market (Kibunyi et al., 2017). Therefore, using a stratified sampling technique, the population of experts and stakeholders with knowledge in the rental market space were identified and divided into six distinct homogeneous strata. Each respondent was assigned to only one stratum, which were mutually exclusive. The stratified technique has the advantage of providing greater precision in terms of responses from each stratum, and as such can guard against an unrepresentative sample (Jewell, 1985; Thompson, 2012). Each stratum was identified based on their direct or indirect interaction with the rental housing market.

The web link to the questionnaires was sent out to these groups via email groups, WhatsApp platforms and personal interviews to elucidate responses within each stratum. The purposive sampling technique was used to identify respondents within each stratum since other means of identifying the same was not possible. However, every effort was made to ensure that the downsides of completing the questionnaires were mitigated through constant reminders. The sample frame was drawn from landlords; tenants; real estate agents (REAs) (within Accra); academic staff in real estate departments from Universities (Kwame Nkrumah University of Science and Technology Kumasi and University for Development Studies Tamale); as well as 
valuation and estate surveyors of the Ghana Institution of Surveyors (GhIS) and a group labelled as 'others' all in Accra (see Figure 4). It must be noted that developers, who are active market participants that would want to maximise returns through client satisfaction are not part of the analysis. Questionnaires were sent out to a group of developers but only 1 developer responded. The rest did not return the questionnaires though it would have been interesting to identify property attributes that possess effective demand from developers' perspective. A number of questionnaires were sent out, and the data analysed in this research was obtained from a response rate of 113 respondents who are perceived to be acquainted with both the formal and informal rental markets in Ghana. The survey was carried out between January and February 2017.

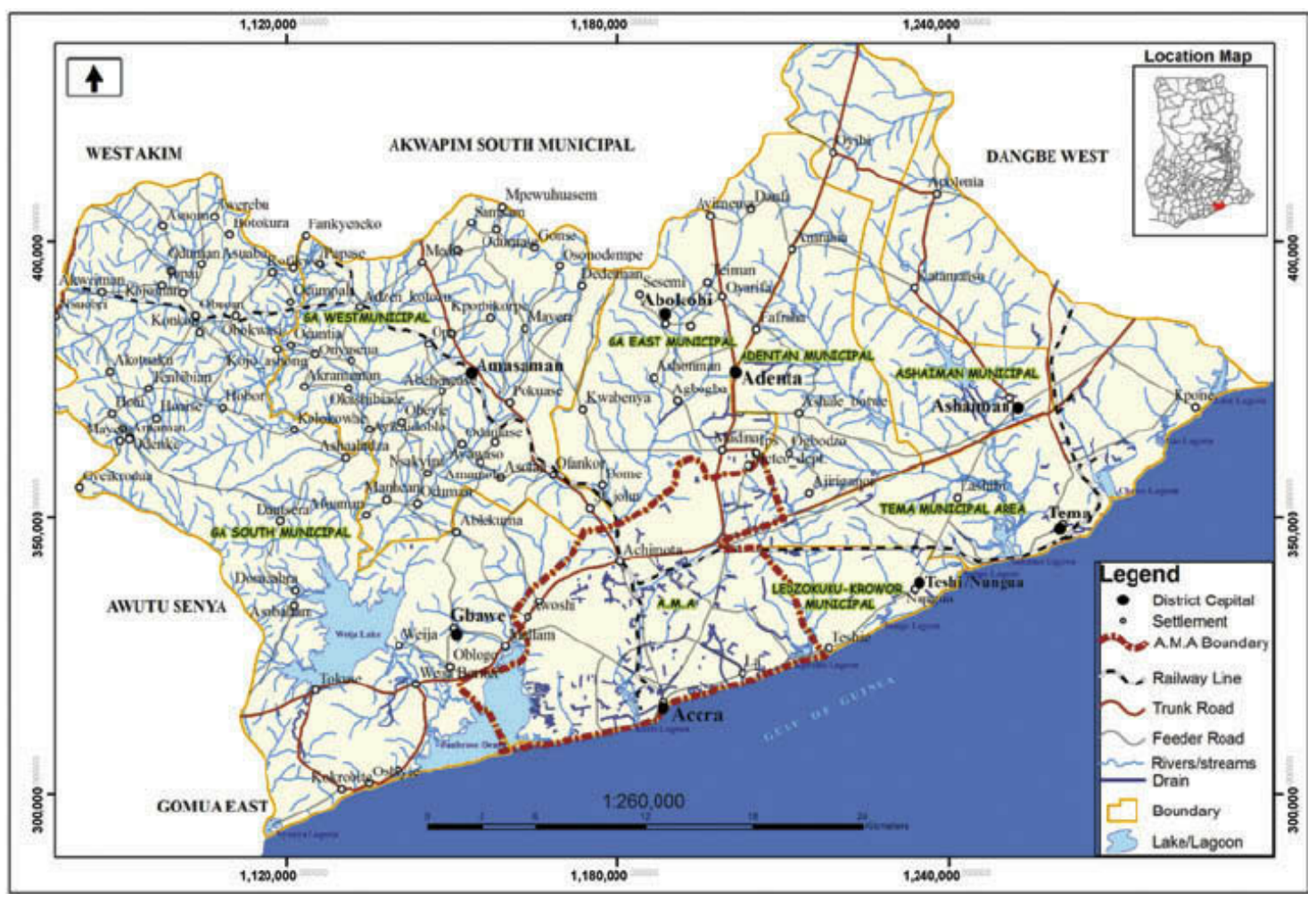

Figure 4: Map of the Greater Accra Region

Source: Centre for Remote Sensing and GIS (CERGIS) University of Ghana, 2013

Both closed and open-ended questions were included in the questionnaire after the pilot test was undertaken to identify potential problems and the feasibility of the following research methodology. The questionnaire ${ }^{2}$ was administered to experts, namely: Academics and Valuation and Estate Surveyors (VES) (members of the Ghana Institution of Surveyors), and stakeholders (landlords, tenants, real estate agents). Academic staff from real estate departments provide the VES, as do other market players with the

\footnotetext{
2 The web-link to the questionnaire is provided here: https://docs.google.com/forms/d/e/1FAIpQLScIJXgdUf9KU0nwSWhbFfFRml2F3NGz6OVqHgVmgc3YG8v5A/viewform?usp=sf link
}

The "Google forms" online platform was used to collect the data. All respondents filled and submitted the questionnaires online. Once the form is submitted the authors received an alert. 
requisite expertise and knowledge (both directly and indirectly). All academic staff respondents are practitioners are also members of the GhIS. VES is the professional body mandated to carry out property valuations (and property management). Their experience and in-depth knowledge about the rental market is critical in understanding how the market operates. In Ghana, the majority of transactions in the rental market is informal and landlords mostly determine rents (seldom with the help of real estate professionals). Landlords have greater control in determining rental values for their properties; hence their inclusion. Anecdotal evidence suggests that most landlords in the informal rental market do not engage the services of estate agents to avoid paying commission. REAs on the other hand act as middle-men for either the landlord and/or the tenant. Some landlords and developers rely on REAs in the sales and letting of properties at a commission. These agents could be differentiated by the kind of properties they manage - high end, middle end and low-end agents. There is currently no licensing regime to certify them or regulatory controls for REAs in Ghana. It should be however noted that professional REAs are regulated by the GhIS. Tenants decide on their location choice based on their perceptions about value in the rental market as such their inclusion. Lastly, there was a respondent group known as 'others'. These did not identify with the categories above but provided useful insights in understanding the phenomenon under study.

A number of explanatory variables were identified through the literature review, and the role of experts and stakeholders were to rank these variables based on their perceptions about how the explanatory variables could be incorporated in defining what is relevant from a purely theoretical perspective. This was seen as a first step to put the research in its relevant local context.

The type of data collected during the survey includes the category of respondents, years of contact with the real estate market, a ranking of variables that determine rental values and a brief description of the rental market in Accra. Accra was selected as the case study area because it is the capital city, has a higher percentage of rentals and a better developed rental market than other parts of the country.

\section{Determinants of Residential Rental Values: Evidence from Key Stakeholder Survey}

From the perspective of a developing country, there is little consensus as to which specific variables determine rental values (Megbolugbe 1989; AnimOdame et al., 2010b; Adegoke 2014). This research takes the approach by first developing a questionnaire for key stakeholders in the rental market in Ghana. The approach utilises a large spectrum of 38 variables identified through the literature review, which may be relevant in identifying key determinants of rental value. Respondents ranked these variables, and the findings are presented in this section.

The data consists of 113 responses from experts and stakeholders. From the sample, landlords, tenants, REAs, academia, VES and the group labelled 
'others' constituted 5\%,35\%,4\%, 20\%, 30\% and 4\% respectively. The questionnaire made available an option known as 'others' for respondents who did not identify themselves with any of the categorised groupings. This group from the survey could be made up of owner-occupiers, sharers and rentfree occupiers of rental property (which include children and relatives of both landlords and tenants).

\subsection{Reliability Analysis - Cronbach Alpha}

To test how reliable the ranked data is, the Cronbach Alpha analysis is used. Theoretically, the values can range between 0 and 1 . Higher values suggest internal consistency and therefore valid conclusions from the data. Nunnally and Bernstein (1979) believe that values between 0.50 and 0.60 and above show strong consistency. However, Hair et al. (2010) posit that $\geq 0.70$ is preferred.

An overall alpha value of 0.963 was realised. This suggests that the data can be relied on to draw valid conclusions. The Cronbach Alpha for each variable, when each variable is deleted, is computed in Table 2. Oyedele (2013) posits that this measures the significance of each variable compared to the overall Cronbach Alpha. The value of a variable equal to or less than the overall alpha value (0.963) suggests a significant contribution of that variable; whereas a value higher than the overall alpha value signifies insignificant contribution. From the data analysed all Cronbach alpha values (when each variable is deleted) is either below or equal to the overall Cronbach alpha value; hence they contribute significantly to internal consistency and retained in the further analysis.

Table 2: Cronbach Alpha Scores for Variables

\begin{tabular}{|l|l|c|}
\hline \multicolumn{2}{|c|}{ Overall Cronbach alpha reliability $\mathbf{0 . 9 6 3}$} \\
\hline \multirow{4}{*}{ Category of factor } & \multicolumn{1}{|c|}{ Name of Variable } & \multicolumn{1}{c|}{$\begin{array}{c}\text { Cronbach alpha when } \\
\text { the variable is deleted }\end{array}$} \\
\hline & $\begin{array}{l}\text { Type of house (e.g. apartment, hall \& chamber, } \\
\text { single room) }\end{array}$ & 0.962 \\
\cline { 2 - 3 } & Quality of construction (\& materials) & 0.962 \\
\cline { 2 - 3 } & Age of building & 0.962 \\
\cline { 2 - 3 } & Plot size & 0.962 \\
\cline { 2 - 3 } & Size of building (floor area) & 0.962 \\
\cline { 2 - 3 } & Number of bedrooms & 0.962 \\
\cline { 2 - 3 } & Number of wc & 0.962 \\
\cline { 2 - 3 } & Number of baths & 0.962 \\
\cline { 2 - 3 } & Floor finish (screed, concrete, tile, terrazzo) & 0.962 \\
\cline { 2 - 3 } & Number of storeys (floors) & 0.963 \\
\cline { 2 - 3 } & Kitchen available (separate or shared) & 0.962 \\
\cline { 2 - 3 } & Toilet available (separate or shared) & 0.961 \\
\cline { 2 - 3 } & Bathroom available (separate or shared) & 0.961 \\
\cline { 2 - 3 } & Property condition (physical deterioration) & 0.961 \\
\hline
\end{tabular}




\begin{tabular}{|c|c|c|}
\hline & Fence or wall availability & 0.961 \\
\hline & Parking space or garage availability & 0.962 \\
\hline & Storeroom availability & 0.963 \\
\hline & Quality of landscaping & 0.962 \\
\hline \multirow{6}{*}{ 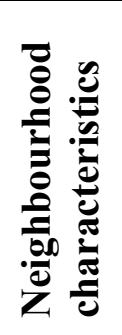 } & Near to suitable vehicular access & 0.961 \\
\hline & Has electricity connection & 0.961 \\
\hline & Has piped-water connection or well & 0.961 \\
\hline & Waste disposal or garbage collection available & 0.961 \\
\hline & Area considered safe (security) & 0.962 \\
\hline & Streetlighting present & 0.962 \\
\hline \multirow{14}{*}{ 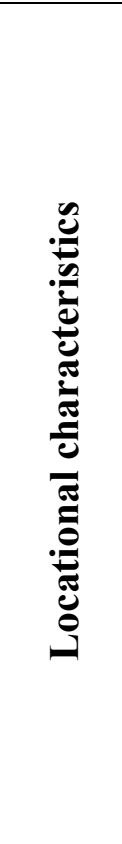 } & Presence of suitable surface drainage & 0.962 \\
\hline & Near to traffic congestion & 0.962 \\
\hline & Near to market or shopping centre & 0.961 \\
\hline & Near to CBD & 0.962 \\
\hline & Near to job opportunities & 0.962 \\
\hline & Near to educational facility & 0.961 \\
\hline & Near to healthcare (medical) facilities & 0.962 \\
\hline & $\begin{array}{l}\text { Near to recreational facilities (parks \& green } \\
\text { spaces) }\end{array}$ & 0.962 \\
\hline & Near to squatter settlements & 0.963 \\
\hline & Near to Police station (security post) & 0.962 \\
\hline & Near to place of worship & 0.962 \\
\hline & Population density & 0.962 \\
\hline & Near to bus stop (public transport) & 0.962 \\
\hline & Quality of property view & 0.962 \\
\hline
\end{tabular}

Source: Author's Construct, 2018.

\subsection{Perceived Effects of Ranked Variables by Stakeholders}

Table 3 provides a summary of the perceived significant effect of each of the ranked variables as perceived by stakeholders. From Table 3, variables ranked as 'significant' or 'highly significant' are also perceived to have a positive effect on rental value. This suggests that when these variables are modelled the signs of their coefficients are expected to be positive and most probably statistically significant. Another group of variables are ranked as neutral in terms of significance and effect on rental value. These are number of storeys (floors), storeroom availability and rental units near to recreational facilities. This result also suggests that these variables may not be statistically significant and may not have any effect on rental value when modelled. This suggests that the effect may be 0 .

The next group of variables are perceived to have a positive effect but no significance on rental value. These variables include: 'age of building', 'plot size', 'number of baths', 'quality of landscaping', 'near to CBD', 'near to job opportunities', 'near to police station', 'near to bus stop' and 'quality of property view'. So, it presupposes that when these variables are modelled in 
a hedonic equation the expected sign of the coefficients may be positive but may not be statistically significant. This seems at variance with the literature on the effects of some of these variables, especially plot size and number of baths. The literature suggests that the coefficients of these variables normally have a positive sign when modelled in a hedonic equation or regression analysis (see Sirmans et al. 2005).

These next set of variables are perceived to have an adverse effect but no significance on rental value. These variables are: 'near to traffic congestion' and 'near to squatter settlements'. Since many residents will generally want to avoid these areas, the perception is that it has a negative effect on rental values, and as such, a negative sign is expected in terms of the coefficient sign when modelled. It may also imply that these variables may not be statistically significant.

Table 3: Perceived Significant Effect of Variables that Determine RRVs by Stakeholders - Overall

\begin{tabular}{|c|c|c|c|c|}
\hline $\begin{array}{l}\text { Category of } \\
\text { factor }\end{array}$ & Name of Variable & Significance & $\begin{array}{l}\text { Effect on rental } \\
\text { value } \\
\text { (expected sign) }\end{array}$ & Comment \\
\hline \multirow{18}{*}{ 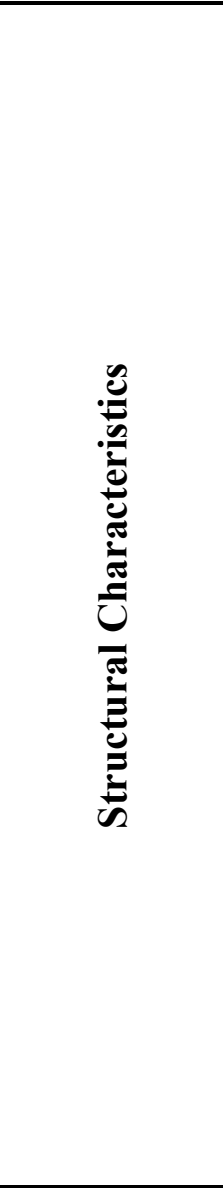 } & $\begin{array}{l}\text { Type of house (e.g. apartment, hall \& } \\
\text { chamber, single room) }\end{array}$ & $\begin{array}{c}\text { Highly } \\
\text { Significant }\end{array}$ & + & \\
\hline & Quality of construction (\& materials) & Significant & + & \\
\hline & Age of building & Neutral & + & Inconclusive \\
\hline & Plot size & Neutral & + & \\
\hline & Size of building (floor area) & Significant & + & \\
\hline & Number of bedrooms & Significant & + & \\
\hline & Number of wc & Significant & + & \\
\hline & Number of baths & Neutral & + & \\
\hline & $\begin{array}{l}\text { Floor finish (screed, concrete, tile, } \\
\text { terrazzo) }\end{array}$ & Significant & + & \\
\hline & Number of storeys (floors) & Neutral & Neutral & Inconclusive \\
\hline & Kitchen available (separate or shared) & Significant & + & \\
\hline & Toilet available (separate or shared) & Significant & + & \\
\hline & Bathroom available (separate or shared) & Significant & + & \\
\hline & $\begin{array}{l}\text { Property condition (physical } \\
\text { deterioration) }\end{array}$ & Significant & + & $\begin{array}{l}\text { Effect could } \\
\text { be negative }\end{array}$ \\
\hline & Fence or wall availability & Significant & + & \\
\hline & Parking space or garage availability & Significant & + & \\
\hline & Storeroom availability & Neutral & Neutral & Neutral \\
\hline & Quality of landscaping & Neutral & + & $\begin{array}{c}\text { Effect could } \\
\text { be neutral }\end{array}$ \\
\hline \multirow{3}{*}{$\begin{array}{l}\text { Neighbour } \\
\text { hood } \\
\text { characteris } \\
\text { tics }\end{array}$} & Near to suitable vehicular access & Significant & + & \\
\hline & Has electricity connection & $\begin{array}{c}\text { Highly } \\
\text { Significant }\end{array}$ & + & \\
\hline & Has piped-water connection or well & $\begin{array}{c}\text { Highly } \\
\text { Significant }\end{array}$ & + & \\
\hline
\end{tabular}




\begin{tabular}{|c|c|c|c|c|}
\hline & $\begin{array}{l}\text { Waste disposal or garbage collection } \\
\text { available }\end{array}$ & Significant & + & \\
\hline & Area considered safe (security) & Significant & + & \\
\hline & Streetlighting present & Significant & + & \\
\hline \multirow{14}{*}{ 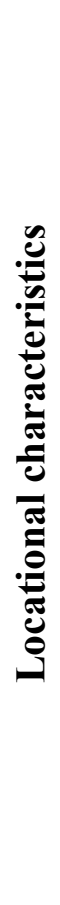 } & Presence of suitable surface drainage & Significant & + & \\
\hline & Near to traffic congestion & Neutral & _- & Inconclusive \\
\hline & Near to market or shopping centre & Significant & + & \\
\hline & Near to CBD & Neutral & + & $\begin{array}{c}\text { Effect could } \\
\text { be neutral }\end{array}$ \\
\hline & Near to job opportunities & Neutral & + & $\begin{array}{c}\text { Effect could } \\
\text { be neutral }\end{array}$ \\
\hline & Near to educational facility & Significant & + & \\
\hline & Near to healthcare (medical) facilities & Significant & + & \\
\hline & $\begin{array}{l}\text { Near to recreational facilities (parks \& } \\
\text { green spaces) }\end{array}$ & Neutral & Neutral & $\begin{array}{l}\text { Effect could } \\
\text { be positive }\end{array}$ \\
\hline & Near to squatter settlements & Neutral & _- & \\
\hline & Near to Police station (security post) & Neutral & + & \\
\hline & Near to place of worship & Neutral & $+I_{-}$ & Inconclusive \\
\hline & Population density & Neutral & +1 & Inconclusive \\
\hline & Near to bus stop (public transport) & Neutral & + & \\
\hline & Quality of property view & Neutral & + & \\
\hline
\end{tabular}

Note: “+” is positive, "--" is negative

Source: Expert/Stakeholder Survey, 2017.

The final set of variables in terms of significance are neutral but could have either positive or negative impacts on rental value. These variables are: 'near to place of worship' and 'population density'. The observed effect here is inconclusive and suggests that when modelled in a hedonic equation the variable coefficient could be positive or negative depending on the empirical data analysed and is probably insignificant.

In general, it must be noted that there is a convergence with some of the variables presented by Sirmans et al. (2005) who are also of the opinion that the number of bathrooms, bedrooms, public rooms, garage and size of rental unit predominantly have a positive effect on rental values. These assertions are based on empirical evidence. It is realised that although respondents' choices are only perceived to be the effects without any empirical basis, it does present a starting point to examine which variables may be relevant in modelling the rental market in a developing country context. It was mentioned earlier that researchers in this field need to be able to identify the 'correct set of variables' that must be incorporated in the rental market analysis.

To conclude, in Table 3, it is realised that most of the variables identified throughout the literature and presented here are perceived to be significant and may have a positive coefficient sign when modelled. This is the first step in identifying variables that may be selected and utilised in empirical data collection. The empirical data will give a strong indication as to the 
conclusions that may be drawn from the selection of these variables, especially in a developing country context.

In the next section, the variables are ranked based on the Relative Importance Index.

\subsection{Relative Importance Index (RII)}

The RII is used to evaluate each variable in order to determine their relative contribution to rental value. This index is computed by utilising all individual variable scores and ranking variables against each other. The frequently cited RII formula as presented by Holt (2014) is adopted:

$$
R I I=\frac{\Sigma W}{A * N}
$$

$$
\text { Where } 0 \leq \mathrm{RII} \leq 1
$$

Where: $\quad W$ is the sum of scores awarded a variable $V_{i}$ from $N$ number of respondents.

The sum of $N$ respondents selecting a response point multiplied by the point's integer value, for an option on the scale term.

$A$ is the largest integer response scale $\left(A_{\max }\right.$, in this case, will be 5).

The index has a value between 0 and 1 . When the value of the index is close to 1 , it suggests that respondents rank that particular variable high, and a rank close to 0 suggests that the variable has a low ranking. The RII computes the 'relative importance' of (independent) variables by comparing the rank attributed to the variable by respondents and also by comparing with other variables that are computed.

Respondents were asked to rank each variable based on a 5-point Likert scale from 1 (highly insignificant) to 5 (highly significant). These RII rankings are computed from the raw scores as provided by respondents and values ranged between 0.48 and 0.97 (see Table A1 in the appendix). Based on the RII computed, each variable is ordered from 1 (highest RII score) to 38 (least RII score) - see Table 4. Colour coding is used to differentiate the categories of variables measured. From Table 4, the median scores for all respondents are provided. The median is utilised as it is resistant to outliers and better represents a measure of central tendency. Although the mean is one of the common measures of central tendency, it cannot be used in this instance because the data are ordinal in nature (i.e. rankings from 1 to 5). 
Table 4: Ranking of the Variables Based on the Relative Importance Index (RII) by Category

\begin{tabular}{|c|c|c|c|c|c|c|c|c|}
\hline Name of Variable & 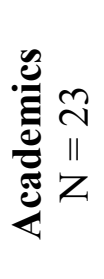 & 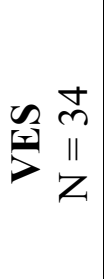 & 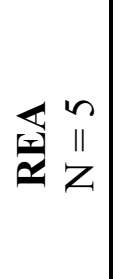 & 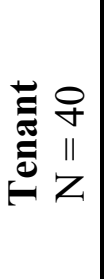 & 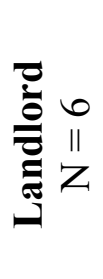 & 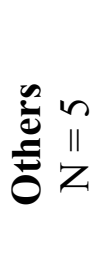 & 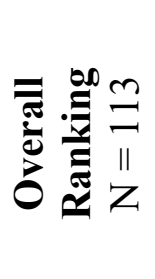 & 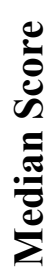 \\
\hline Has electricity connection & 1 & 1 & 3 & 1 & 1 & 1 & 1 & 5 \\
\hline $\begin{array}{l}\text { Type of house (e.g. apartment, hall \& } \\
\text { chamber, single room) }\end{array}$ & 1 & 2 & 1 & 2 & 6 & 2 & 2 & 5 \\
\hline Has piped-water connection or well & 3 & 3 & 3 & 3 & 1 & 2 & 3 & 5 \\
\hline $\begin{array}{ll}\begin{array}{l}\text { Property } \\
\text { deterioration) }\end{array} & \text { condition } \\
\end{array}$ & 4 & 4 & 1 & 3 & 10 & 11 & 4 & 4 \\
\hline Number of bedrooms & 5 & 8 & 6 & 5 & 1 & 4 & 5 & 4 \\
\hline Area considered safe (security) & 6 & 4 & 3 & 8 & 4 & 4 & 6 & 4 \\
\hline Toilet available (separate or shared) & 8 & 6 & 8 & 5 & 6 & 4 & 7 & 4 \\
\hline $\begin{array}{l}\begin{array}{l}\text { Bathroom available } \\
\text { shared) }\end{array} \\
\end{array}$ & 8 & 6 & 13 & 5 & 6 & 4 & 7 & 4 \\
\hline Kitchen available (separate or shared) & 12 & 10 & 13 & 9 & 9 & 8 & 9 & 4 \\
\hline Quality of construction ( $\&$ materials) & 11 & 9 & 8 & 13 & 35 & 16 & 10 & 4 \\
\hline Size of building (floor area) & 8 & 10 & 8 & 15 & 10 & 11 & 11 & 4 \\
\hline Near to suitable vehicular access & 7 & 14 & 6 & 10 & 21 & 11 & 11 & 4 \\
\hline $\begin{array}{l}\text { Floor finish (screed, concrete, tile, } \\
\text { terrazzo) }\end{array}$ & 12 & 12 & 13 & 10 & 24 & 28 & 11 & 4 \\
\hline $\begin{array}{l}\text { Waste disposal or garbage collection } \\
\text { available }\end{array}$ & 14 & 13 & 8 & 14 & 4 & 16 & 14 & 4 \\
\hline Fence or wall availability & 19 & 18 & 25 & 12 & 10 & 8 & 15 & 4 \\
\hline Presence of suitable surface drainage & 15 & 15 & 29 & 26 & 10 & 8 & 16 & 4 \\
\hline Near to healthcare (medical) facilities & 23 & 16 & 8 & 20 & 10 & 22 & 16 & 4 \\
\hline Number of wc & 23 & 26 & 18 & 20 & 10 & 11 & 18 & 4 \\
\hline Parking space or garage availability & 22 & 26 & 19 & 18 & 30 & 11 & 18 & 4 \\
\hline Streetlighting present & 16 & 24 & 33 & 20 & 21 & 22 & 18 & 4 \\
\hline Near to squatter settlements & 23 & 20 & 19 & 16 & 24 & 34 & 18 & 3 \\
\hline Number of baths & 30 & 33 & 19 & 20 & 10 & 16 & 22 & 3 \\
\hline Near to educational facility & 23 & 20 & 13 & 31 & 10 & 20 & 22 & 4 \\
\hline Near to CBD & 16 & 26 & 13 & 26 & 37 & 20 & 22 & 3 \\
\hline Near to market or shopping centre & 18 & 24 & 33 & 20 & 24 & 22 & 22 & 4 \\
\hline Quality of property view & 32 & 20 & 25 & 16 & 10 & 34 & 22 & 3 \\
\hline Near to traffic congestion & 19 & 20 & 25 & 26 & 21 & 34 & 22 & 3 \\
\hline Age of building & 30 & 30 & 32 & 18 & 24 & 22 & 28 & 3 \\
\hline Near to bus stop (public transport) & 23 & 35 & 19 & 20 & 30 & 16 & 29 & 3 \\
\hline Near to job opportunities & 29 & 26 & 25 & 32 & 24 & 22 & 29 & 3 \\
\hline Near to Police station (security post) & 36 & 16 & 36 & 30 & 10 & 28 & 29 & 3 \\
\hline
\end{tabular}




\begin{tabular}{|l|l|l|l|l|l|l|l|l|}
\hline Plot size & 23 & 19 & 19 & 36 & 33 & 28 & 29 & 3 \\
\hline Population density & 33 & 34 & 19 & 26 & 24 & 33 & 33 & 3 \\
\hline Number of storeys (floors) & 19 & 30 & 29 & 32 & 33 & 34 & 33 & 3 \\
\hline Quality of landscaping & 33 & 30 & 37 & 34 & 35 & 34 & 35 & 3 \\
\hline Near to place of worship & 38 & 37 & 33 & 37 & 10 & 28 & 36 & 3 \\
\hline $\begin{array}{l}\text { Near to recreational facilities (parks \& } \\
\text { green spaces) }\end{array}$ & 35 & 35 & 29 & 38 & 32 & 28 & 37 & 3 \\
\hline Storeroom availability & 36 & 38 & 37 & 35 & 38 & 22 & 38 & 3 \\
\hline
\end{tabular}

Source: Expert/ Stakeholder Survey, 2017.

Structural characteristics

Neighbourhood characteristics

Locational characteristics
Note:

'Academic' represents - academic (real estate and related fields)

'VES' represents - Valuation and Estate Surveyor (GhIS)

It can be realised from Table 4 that the following variables are generally ranked very high: electricity connection, piped-water connection, type of house, property condition and number of bedrooms. For example, it is striking to notice that among the category landlords, a variable like property condition, which was expected to be ranked probably among the top 5, rather had a rank of $10^{\text {th }}$ position. The same can be realised from the quality of construction material which ranks $35^{\text {th }}$. Could it mean that landlords generally do not extend much importance to the quality of construction materials and property conditions when they decide on rental value? If this assertion is right, then it could also suggest that the motive of landlords would be to rent out their properties irrespective of the condition or quality of construction materials and still expect to make higher returns.

It should also be observed that within the tenants' stratum, availability of basic utilities (electricity and water connection), property type, property condition and the number of bedrooms are topmost determinants of rental value. The availability of basic utilities seems to cut across all groups. A general trend realised is that neighbourhood, and structural characteristics are ranked higher followed by locational characteristics.

\subsection{Omitted Variables}

In order to ensure that no variables have been possibly omitted, respondents were asked to indicate whether any variables may have been omitted. The results to the question, 'Are there other variables that may have been omitted?' are presented below.

It was realised that majority of the respondents (47\%) were not sure whether some variables were omitted or otherwise. It is acknowledged that it may be difficult to identify the 'correct set of variables' that together make up the rental value. Although this may be the case, we are of the view that most of the relevant variables have been identified in this research. About $31 \%$ of respondents are of the opinion that no variables had been omitted. Twenty three percent of respondents felt that there were omitted variables that ought to be included. These included the following; 
- availability of telecommunication infrastructure,

- whether location or neighbourhood is flood prone,

- the presence of landlord in the same facility,

- environmental pollution levels in the neighbourhood,

- type of tenant (e.g. government, private company or individual),

- type of land tenure arrangement, and

- quality of property management.

In terms of further research into this phenomenon, other researchers are encouraged to consider their inclusion and test how stakeholders will rank these variables in terms of the effect on rental value.

\subsection{Which Variables Drive Residential Rental Values?}

Based on the foregoing, an attempt has been made to discuss stakeholder perceptions of rental value determinants. The research provides a summary of the effects of structural, neighbourhood and locational characteristics in giving guidance as to which of these broad categories determine residential rental values in Ghana. Figure 5 shows the median values of RII for each category of respondent as computed from raw scores. The median is preferred in this instance as it is robust and not affected by skewed data. Respondents are in general agreement and suggest that in terms of ranking from the highest to the lowest (based on median RII), neighbourhood characteristics are ranked highest, then followed closely with structural characteristics and then locational characteristics rank third.

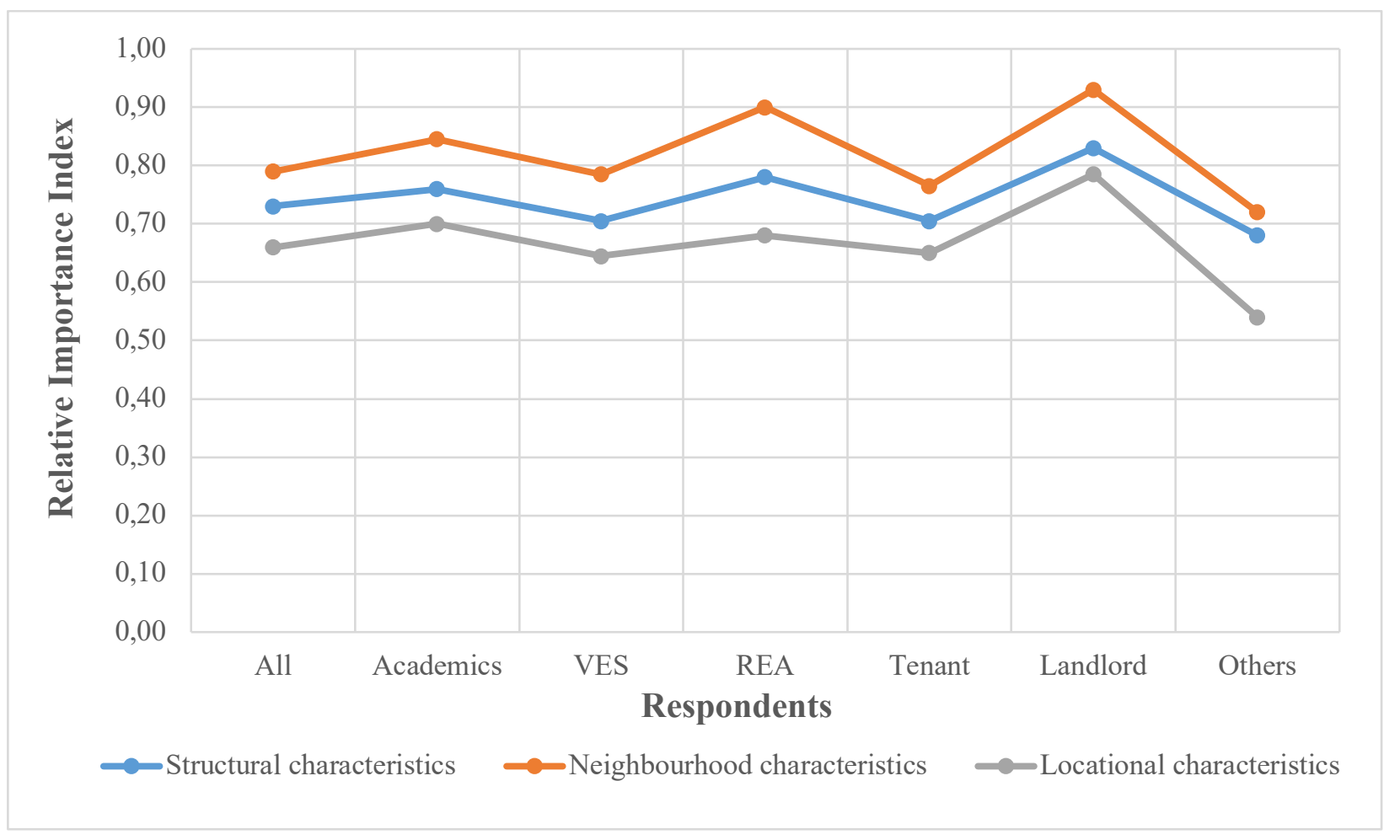

Figure 5: Relative Importance Index of Structural, Neighbourhood and Locational Characteristics

Source: Expert/ Stakeholder Survey, 2017. 


\section{Conclusions and Implications}

This paper contributes to the discussion on rental value determinants by extending the spatial scope in a developing country context. The paper bridges the gaps in previous studies by incorporating a broader spectrum of stakeholders in the quest to identify rental value determinants based on expert and stakeholder perceptions.

Respondents agreed that the variables, such as: 'electricity connection', 'piped water connection', 'type of house', 'property condition' and 'the number of bedrooms' ranked among the most significant variables per the RII computed. Respondents also perceived that the variables, such as: 'storeroom availability', 'rental units near to recreational facilities', 'near the place of worship', 'quality of landscaping' and 'number of storeys' ranked among the least significant variables based on the RII computed. These responses suggest that the presence or absence of these intrinsic and extrinsic characteristics may not have any significant effect on rental values. The results suggest that when variables are grouped and ranked from the highest to the lowest (based on median RII), neighbourhood characteristics are ranked highest, followed by structural characteristics, and then locational characteristics rank third. Thus, anecdotal evidence suggesting that location is a key determinant of value is not supported in this research.

Although these findings represent experts and stakeholders' perception about the price decomposition of the residential rental market, these results in themselves are not conclusive unless empirical studies are undertaken to ascertain the veracity of the findings. This research acknowledges this limitation and suggest further empirical research to test key rental value determinants.

In terms of policy direction, the relevant district assemblies and government agencies responsible for housing and infrastructure planning must ensure that there is adequate provision of basic infrastructure to ensure that the objective of the national housing policy aimed at 'creating viable and sustainable communities through the provision of adequate, decent and affordable housing that is accessible and sustainable to satisfy the needs of Ghanaians' is achieved (Government of Ghana, 2015: p.14). Further studies can explore how these perceptions of value feed into actual rental values observed in the housing market and the interrelationships that may exist.

\section{Acknowledgement}

The authors want to thank anonymous reviewers for their careful reading of manuscripts, comments and suggestions that have significantly improved earlier drafts of the paper. Authors are also grateful to the Government of Ghana and the German Academic Exchange Services (DAAD) for providing the scholarship for the doctoral programme on which this article is based. 


\section{References}

Abidoye, R.B. \& Chan, A.P.C. (2016). Critical determinants of residential property value: professionals' perspective. Journal of Facilities Management, 14(3), pp.283-300. https://doi.org/10.1108/JFM-02-20160003

Adegoke, O.J. (2014). Critical factors determining rental value of residential property in Ibadan metropolis, Nigeria. Property Management, 32(3), pp.224-240. https://doi.org/10.1108/PM-05-2013-0033

Amenyah, I.D. \& Fletcher, E.A. (2013). Factors determining residential rental prices. Asian Economic and Financial Review, 3(1), pp.39-50.

Anim-Odame, W.K., Key, T. \& Stevenson, S. (2010a). Residential market development in sub-Saharan Africa. International Journal of Housing Markets and Analysis, 3, 308-326.

Anim-Odame, W.K., Key, T. \& Stevenson, S. (2010b). The Ghanaian transaction based residential indices. International Journal of Housing Markets and Analysis, 3(3), 216-232. Available at: http://dx.doi.org/10.1108/17538271011063889

Arimah, B.C. (1992). Hedonic Prices and the Demand for Housing Attributes in a Third World City: The Case of Ibadan, Nigeria. Urban Studies, 29(5), 639-651. https://doi.org/10.1080/00420989220080601

Arku, G. (2009a). Housing and development strategies in Ghana, 1945-2000. International Development Planning Review, 28, pp.333-358. https://doi.org/10.3828/idpr.28.3.3

Arku, G. (2009b). Housing Policy Changes in Ghana in the 1990s. Housing Studies, 24(2), pp.261-272. https://doi.org/10.1080/02673030902719763

Arku, G., Luginaah, I. \& Mkandawire, P. (2012). You Either Pay More Advance Rent or You Move Out: Landlords/Ladies' and Tenants' Dilemmas in the Low-income Housing Market in Accra, Ghana. Urban Studies, 49(14), pp.3177-3193.

Asabere, P. (2007). The demise of the rent-controlled public housing programmes of ghana: The story of the Tema Development Corporation. Urban Studies, 44(10), pp.1919-1935. https://doi.org/10.1080/00420980701471893

Asabere, P.K. (2004). The pricing of the emergent leasehold (possessory) estates of Ghana. Real Estate Economics, 32(4), pp.673-694. https://doi.org/10.1111/j.1080-8620.2004.00107.x

Asante, L.A., Gavu, E.K., Quansah, D. P. O. \& Osei Tutu, D. (2018). The difficult combination of renting and building a house in urban Ghana: analysing the perception of low and middle income earners in Accra. GeoJournal, 83, pp.1223-1237. https://doi.org/10.1007/s10708-017$\underline{9827-2}$

Baffour Awuah, K.G., Proverbs, D., Lamond, J. \& Gyamfi-Yeboah, F. (2016). An Evaluation of Property Valuation Practice in Sub-Saharan Africa: A Case Study of Ghana. London. Available at: http://www.rics.org/Global/Property_Valuation_Ghana_180216_dwl_a a.pdf

Ball, M. (1977). Differential rent and the role of landed property. International Journal of Urban and Regional Research, 1, pp.380-403. 
Ball, M. (1985a). Land rent and the construction industry. In M. Ball, V. Bentivegna, M. Edwards, \& M. Folin (Eds.), Land Rent, Housing and Urban Planning: A European Perspective. London: Croom Helm.

Ball, M. (1985b). The Urban Rent Question. Environment and Planning A: Economy and Space, 17(4), pp.503-525.

Buckley, R.M. \& Mathema, A. S. (2007). Is Accra a Superstar City? World Bank Policy Research Working Paper Series (Vol. 4453).

Choumert, J., Kere, E.N. \& Laré, A.L. (2015). The impact of water and sanitation access on housing values: The case of Dapaong, Togo. Available at: $\quad$ https://halshs.archives-ouvertes.fr/halshs$00939267 \mathrm{v} 2 /$ document

Connolly, N.D.B. (2014). A World More Concrete: Real Estate and the Remaking of Jim Crow South Florida. Volume 114 of Historical Studies of Urban America (illustrate). Chicago and London: The University of Chicago Press.

De, U.K. \& Vupru, V. (2017). Location and neighbourhood conditions for housing choice and its rental value: Empirical examination in an urban area of North-East India. International Journal of Housing Markets and Analysis. https://doi.org/10.1108/IJHMA-10-2016-0072

Ghana Statistical Service. (2014). Ghana Living Standards Survey Round 6 (GLSS 6). Accra.

Gilbert, A. (2016). Rental housing: The international experience. Habitat International, 54, pp.173-181.

Gough, K. \& Yankson, P.(2000). Land Markets in African Cities: The Case of Peri-urban Accra, Ghana. Urban Studies, 37(13), pp.2485-2500. https://doi.org/10.1080/00420980020080651

Gough, K.V. \& Yankson, P. (2011). A Neglected Aspect of the Housing Market: The Caretakers of Peri-urban Accra, Ghana. Urban Studies, 48(4), pp.793-810. https://doi.org/10.1177/0042098010367861

Government of Ghana. (2015). Ghana National Spatial Data Framework (2015-2030), Volume I: Conditions and Main Issues. Available at: https://www.ghanalap.gov.gh/files/NSDF-Final-Report-Vol-I-FinalEdition-TAC.pdf

Gulyani, S. \& Talukdar, D. (2008). Slum Real Estate: The Low-Quality HighPrice Puzzle in Nairobi's Slum Rental Market and its Implications for Theory and Practice. World Development, 36(10), pp.1916-1937. https://doi.org/10.1016/j.worlddev.2008.02.010

Haila, A. (2016). Urban Land Rent: Singapore as a Property State. (J. Robinson, M. Aalbers, D. Brantz, P. Le Gales, C. Pickvance, A. Roy, \& F. Wu, Eds.), Studies in Urban and Social Change Series (First). Chichester: John Wiley \& Sons, Ltd.

Hair, J.F., Anderson, R.E., Tatham, R.L. \& Black, W.C. (2010). Multivariate Data Analysis: A Global Perspective (7th Edition). Pearson Prentice Hall, New Jersey.

Harrison, D. \& Rubinfeld, D.L. (1978). Hedonic housing prices and the demand for clean air. Journal of Environmental Economics and Management, 5(1), pp.81-102. https://doi.org/10.1016/00950696(78)90006-2

Harvey, D. (1973). Social Justice and the City. Baltimore: The Johns Hopkins University Press. https://doi.org/10.1111/j.1467-8330.1974.tb00606.x 
Helbich, M., Brunauer, W., Vaz, E. \& Nijkamp, P. (2013). Spatial Heterogeneity in Hedonic House Price Models:The Case of Austria. Urban Studies, pp.1-22.

Holt, G.D. (2014). Asking questions, analysing answers: relative importance revisited. Construction Innovation: Information, Process, Management, 14(1), pp.2-16. https://doi.org/10.1108/CI-06-2012-0035

International Valuation Standards Council. (2017). International Valuation Standards (2017). IVSC. London: IVSC. Available at: http://www.cas.org.cn/docs/2017-01/20170120142445588690.pdf

Jewell, N.P. (1985). Least squares regression with data arising from stratified samples of the dependent variable. Biometrika, 72(1), pp.11-21. https://doi.org/10.1093/biomet/72.1.11

Kibunyi, D., Wagura Ndiritu, S., Carcel, H. \& Gil-Alana, L.A. (2017). Real estate prices in Kenya: is there a bubble? Journal of Housing and the Built Environment, 32(4), pp.787-804. https://doi.org/10.1007/s10901017-9541-X

Knight, J.R., Herrin, W.E. \& Balihuta, A.M. (2004). Housing Prices and Maturing Real Estate Markets: Evidence from Uganda. Journal of Real Estate Finance \& Economics, 28(1), pp.5-18.

Lancaster, K.J. (1966). A New Approach to Consumer Theory. Journal of Political Economy, 74(2), pp.132-156. Available at: http://www.jstor.org/stable/1828835

Lipietz, A. (1985). A Marxist Approach to Urban Ground Rent: the case of France. In M. Ball, V. Bentivegna, M. Edwards, \& M. Folin (Eds.), Land Rent, Housing and Urban Planning: A European Perspective. London: Croom Helm. https://doi.org/10.4324/9781351026147-7

Lundgren, B. (2013). Customer-perceived Value in Residential Developments: the Case of Hornsberg Strand, Sweden. International Real Estate Review, 16(1), pp.1-27. Available at: https://www.um.edu.mo/fba/irer/papers/past/vol16n1_pdf/01.pdf

Mahama, C. \& Adarkwa, K. (2006). Land and Property Markets in Ghana. In A discussion paper prepared by the Royal Institution of Chartered Surveyors for presentation at the 2006 World Urban Forum. London: Royal Institution of Chartered Surveyors.

Malpezzi, S. (2002). Hedonic Pricing Models: A Selective and Applied Review. In T. O’Sullivan \& K. Gibb (Eds.), Housing Economics and Public Policy (pp. 67-89). Oxford: Blackwell Science Ltd, Oxford, UK. https://doi.org/10.1002/9780470690680.ch5

Megbolugbe, I.F. (1989). A Hedonic Index Model: The Housing Market of Jos Nigeria. Urban Studies , 26, pp.486 - 494.

Nunnally, J.C. \& Bernstein, I.H. (1979). Psychometric theory. PsycCRITIQUES, 24, pp.275-280. https://doi.org/10.1037/018882

Obeng-Odoom, F. (2011a). Private Rental Housing in Ghana: Reform or Renounce? Journal of International Real Estate and Construction Studies, 1(1), pp.71-90.

Obeng-Odoom, F. (2011b). Real estate agents in Ghana: A suitable case for Regulation? Regional Studies, 45(3), pp.403-416. https://doi.org/10.1080/00343400903241550

Obeng-Odoom, F. (2015). The Social, Spatial, and Economic Roots of Urban Inequality in Africa: Contextualizing Jane Jacobs and Henry George. 
American Journal of Economics and Sociology, 74(3), pp.550-586. https://doi.org/10.1111/ajes.12101

Owusu-Ansah, A. (2012a). Examination of the Determinants of Housing Values in Urban Ghana and Implications for Policy Makers. Journal of African Real Estate Research, 2(1), pp.58-85.

Owusu-Ansah, A. (2012b). The Dynamics of Residential Property Values in Developing Markets. The case of Kumasi, Ghana. Journal of International Real Estate and Construction Studies, 2(1-2), pp.19-35.

Owusu-Ansah, A. \& Abdulai, R.T. (2014). Producing hedonic price indices for developing markets: Explicit time variable versus strictly crosssectional models. International Journal of Housing Markets and Analysis, 7(4), pp.444-458.

Owusu-Ansah, A., Adolwine, W.M. \& Yeboah, E. (2017). Construction of Real Estate Price Indices for Developing Housing Markets. Does Temporal Aggregation Matter? International Journal of Housing Markets and Analysis, 10(3), pp.371-383. https://doi.org/10.1108/IJHMA-06-2016-0047

Owusu-Ansah, A., Ohemeng-Mensah, D., Abdulai, R.T. \& Obeng-Odoom, F. (2018). Public Choice Theory and Rental Housing: An examination of rental housing contracts in Ghana. Housing Studies, 33(6), pp.938959. https://doi.org/10.1080/02673037.2017.1408783

Oyedele, L.O. (2013). Avoiding performance failure payment deductions in PFI/PPP projects: model of critical success factors. Journal of Performance of Constructed Facilities, 27(3), pp.283-294.

Ozanne, L. \& Thibodeau, T. (1983). Explaining metropolitan housing price differences. Journal of Urban Economics, 13, pp.51-66. https://doi.org/10.1016/0094-1190(83)90045-1

Predöhl, A. (1928). The Theory of Location in Its Relation to General Economics. Journal of Political Economy, 36(3), pp.371-390. Available at: http://www.jstor.org/stable/1822752

Ratcliff, R.U. (1961). Real Estate Analysis. McGraw-Hill, USA.

Roulac, S.E. (2001). Stephen Roulac on place and property strategy. San Francisco: Property Press.

Roulac, S.E. (2007). Brand + beauty + utility $=$ property value. Property Management, 25(5), pp.428-446.

Salifu Osumanu, I., Aigbavboa, C.O. \& Thwala, D.W. (2018). Examining the Relationship Between Lean Adopotion and Housing Finance in Ghana. In S. Fukuda (Ed.), Proceedings of the AHFE 2018 International Conference on Affective and Pleasurable Design, July 21-25 2018 (pp.301-311). Orlando Florida: Springer.

Sirmans, G.S., Macpherson, D. \& Zietz, E.N. (2005). The Composition of Hedonic Pricing Models. Journal of Real Estate Literature, 13(1), pp.144.

Thompson, S.K. (2012). Stratified Sampling. In W.A. Shewhart \& S.S. Wilks (Eds.), Sampling; Wiley Series in Probability and Statistics (3rd ed., pp.139-156). Hoboken, New Jersey: John Wiley \& Sons.

Tipple, G.A. \& Korboe, D. (1998). Housing policy in Ghana: towards a supply-oriented future. Habitat International, 22(3), pp.245-257. https://doi.org/10.1016/S0197-3975(98)00009-5

Tse, R.Y.C. (2002). Estimating Neighbourhood Effects in House Prices: 
Towards a New Hedonic Model Approach. Urban Studies, 39(7), pp.1165-1180. https://doi.org/10.1080/00420980220135545

UN-Habitat. (2011a). Ghana Housing Profile. Nairobi. Available at: https://unhabitat.org/books/ghana-housing-profile/

UN-Habitat. (2011b). Rental Housing: A Much Neglected Housing Option for the Poor. Nairobi.

UNESCAP, \& UN-HABITAT. (2008). Housing the poor in Asian cities, Quick Guides for Policy Makers 7 (7). Bangkok and Kenya. Available at:

http://www.iut.nu/Literature/Asia/HousingThePoorAsia_UNHabitat 2 008.pdf

Wilson, W.J. (2012). The Truly Disadvantaged: The Inner City, the Underclass and Public Policy. University of Chicago Press Economics Books (2nd ed.). Chicago and London: The University of Chicago Press.

Wilson, William Julius. (1992). Another Look at The Truly Disadvantaged. Political Science Quarterly, 106(4), pp.639-656.

Yankson, P.W.K. (2012). Rental Housing and Tenancy Dynamics with particular focus on Low-Income Households in Greater Accra Metropolitan Area. In E. Ardayfio-Schandorf, P.W.K. Yankson, \& M. Bertrand (Eds.), The mobile city of Accra: Urban families, Housing and Residental practices (pp. 183-206). Dakar: Council for the Development of Social Science Research in Africa (CODESRIA). Available at: www.codesria.org

Zeithaml, V.A. (1988). Consumer Perceptions of Price, Quality, and Value: A Means-end-chain Model and Synthesis of Evidence. Journal of Marketing, 25, pp.2-22. https://doi.org/10.2307/1251446

9. Appendix

Table A1: Relative Importance Index of Variables by Category

\begin{tabular}{|c|c|c|c|c|c|c|c|c|}
\hline $\begin{array}{l}\text { Category of } \\
\text { factor }\end{array}$ & Name of Variable & 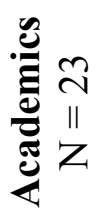 & 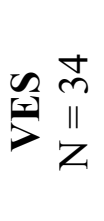 & 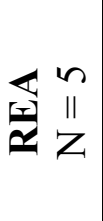 & 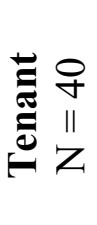 & 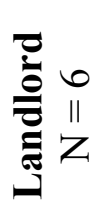 & 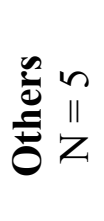 & 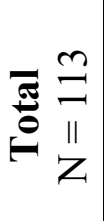 \\
\hline \multirow{10}{*}{ 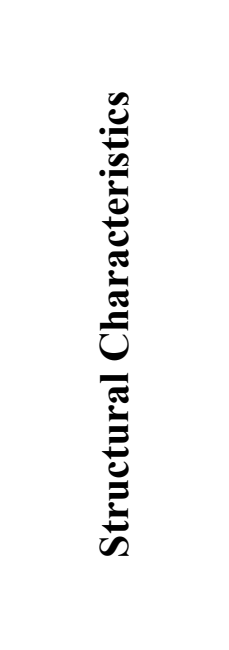 } & $\begin{array}{l}\text { Type of house (e.g. apartment, hall \& } \\
\text { chamber, single room) }\end{array}$ & 0.92 & 0.89 & 0.96 & 0.85 & 0.90 & 0.80 & 0.88 \\
\hline & Quality of construction (\& materials) & 0.80 & 0.79 & 0.84 & 0.72 & 0.63 & 0.64 & 0.76 \\
\hline & Age of building & 0.67 & 0.61 & 0.60 & 0.67 & 0.77 & 0.56 & 0.65 \\
\hline & Plot size & 0.70 & 0.66 & 0.72 & 0.58 & 0.67 & 0.52 & 0.64 \\
\hline & Size of building (floor area) & 0.82 & 0.76 & 0.84 & 0.69 & 0.83 & 0.68 & 0.75 \\
\hline & Number of bedrooms & 0.89 & 0.83 & 0.88 & 0.81 & 0.97 & 0.76 & 0.84 \\
\hline & Number of wc & 0.70 & 0.62 & 0.76 & 0.66 & 0.83 & 0.68 & 0.67 \\
\hline & Number of baths & 0.67 & 0.60 & 0.72 & 0.66 & 0.83 & 0.64 & 0.66 \\
\hline & $\begin{array}{l}\text { Floor finish (screed, concrete, tiled, } \\
\text { terrazzo) }\end{array}$ & 0.79 & 0.74 & 0.80 & 0.74 & 0.77 & 0.52 & 0.75 \\
\hline & Number of storeys (floors) & 0.73 & 0.61 & 0.64 & 0.62 & 0.67 & 0.44 & 0.63 \\
\hline
\end{tabular}


Journal of African Real Estate Research Volume 4(1) 2019

\begin{tabular}{|c|c|c|c|c|c|c|c|c|}
\hline & Kitchen available (separate or shared) & 0.79 & 0.76 & 0.80 & 0.77 & 0.87 & 0.72 & 0.78 \\
\hline & Toilet available (separate or shared) & 0.82 & 0.84 & 0.84 & 0.81 & 0.90 & 0.76 & 0.82 \\
\hline & Bathroom available (separate or shared) & 0.82 & 0.84 & 0.80 & 0.81 & 0.90 & 0.76 & 0.82 \\
\hline & $\begin{array}{lll}\begin{array}{l}\text { Property } \\
\text { deterioration) }\end{array} & \text { condition } & \text { (physical } \\
\end{array}$ & 0.90 & 0.85 & 0.96 & 0.83 & 0.83 & 0.68 & 0.85 \\
\hline & Fence or wall availability & 0.73 & 0.67 & 0.68 & 0.73 & 0.83 & 0.72 & 0.71 \\
\hline & Parking space or garage availability & 0.71 & 0.62 & 0.72 & 0.67 & 0.73 & 0.68 & 0.67 \\
\hline & Storeroom availability & 0.59 & 0.49 & 0.48 & 0.59 & 0.57 & 0.56 & 0.55 \\
\hline & Quality of landscaping & 0.64 & 0.61 & 0.48 & 0.60 & 0.63 & 0.44 & 0.60 \\
\hline \multirow{6}{*}{ 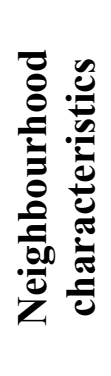 } & Near to suitable vehicular access & 0.83 & 0.71 & 0.88 & 0.74 & 0.80 & 0.68 & 0.75 \\
\hline & Has electricity connection & 0.92 & 0.92 & 0.92 & 0.87 & 0.97 & 0.84 & 0.90 \\
\hline & Has piped-water connection or well & 0.91 & 0.88 & 0.92 & 0.83 & 0.97 & 0.80 & 0.87 \\
\hline & $\begin{array}{l}\text { Waste disposal or garbage collection } \\
\text { available }\end{array}$ & 0.78 & 0.72 & 0.84 & 0.70 & 0.93 & 0.64 & 0.74 \\
\hline & Area considered safe (security) & 0.86 & 0.85 & 0.92 & 0.79 & 0.93 & 0.76 & 0.83 \\
\hline & Streetlighting present & 0.75 & 0.64 & 0.56 & 0.66 & 0.80 & 0.56 & 0.67 \\
\hline \multirow{14}{*}{ 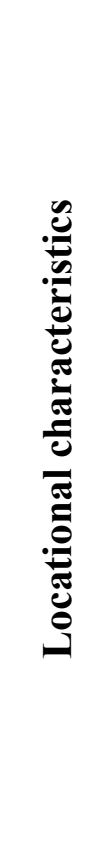 } & Presence of suitable surface drainage & 0.77 & 0.69 & 0.64 & 0.65 & 0.83 & 0.72 & 0.69 \\
\hline & Near to traffic congestion & 0.73 & 0.65 & 0.68 & 0.65 & 0.80 & 0.44 & 0.66 \\
\hline & Near to market or shopping centre & 0.74 & 0.64 & 0.56 & 0.66 & 0.77 & 0.56 & 0.66 \\
\hline & Near to CBD & 0.75 & 0.62 & 0.80 & 0.65 & 0.60 & 0.60 & 0.66 \\
\hline & Near to job opportunities & 0.69 & 0.62 & 0.68 & 0.62 & 0.77 & 0.56 & 0.64 \\
\hline & Near to educational facility & 0.70 & 0.65 & 0.80 & 0.63 & 0.83 & 0.60 & 0.66 \\
\hline & Near to healthcare (medical) facilities & 0.70 & 0.68 & 0.84 & 0.66 & 0.83 & 0.56 & 0.69 \\
\hline & $\begin{array}{l}\text { Near to recreational facilities (parks \& } \\
\text { green spaces) }\end{array}$ & 0.60 & 0.55 & 0.64 & 0.53 & 0.70 & 0.52 & 0.56 \\
\hline & Near to squatter settlements & 0.70 & 0.65 & 0.72 & 0.68 & 0.77 & 0.44 & 0.67 \\
\hline & Near to Police station (security post) & 0.59 & 0.68 & 0.52 & 0.64 & 0.83 & 0.52 & 0.64 \\
\hline & Near to place of worship & 0.58 & 0.54 & 0.56 & 0.57 & 0.83 & 0.52 & 0.57 \\
\hline & Population density & 0.64 & 0.59 & 0.72 & 0.65 & 0.77 & 048 & 0.63 \\
\hline & Near to bus stop (public transport) & 0.70 & 0.55 & 0.72 & 0.66 & 0.73 & 0.64 & 0.64 \\
\hline & Quality of property view & 0.66 & 0.65 & 0.68 & 0.68 & 0.83 & 0.44 & 0.66 \\
\hline
\end{tabular}

Source: Expert/Stakeholder Survey, 2017.

N.B.

Academic represents - academic (real estate and related fields)

VES represents - Valuation and Estate Surveyor (GhIS)

REA represents - Real Estate Agent 